Received: 08 Dez. 2019 - Approved: 26 Fev. 2021 Evaluation Process: Double Blind Review https://doi.org/10.5585/geas.v10i1.16148 e-ISSN: 2316-9834

\title{
Barriers regarding environmental sustainability in civil construction logistics in Curitiba/PR
}

\author{
(iD) Wiliam de Assis Silva' ${ }^{1}$ Robson Seleme ${ }^{2}$ iD Izabel Cristina Zattar ${ }^{3}$ (D) Marcos Augusto \\ Mendes Marques ${ }^{4}$ (Dabiano Oscar Drozda ${ }^{5}$ (D) Mariana Kleina $^{6}$
}

\author{
${ }^{1}$ Mestre em Engenharia de Produção. Universidade Federal do Paraná - UFPR. Curitiba, Paraná - Brasil. \\ wiliamdeassis@gmail.com \\ ${ }^{2}$ Doutor em Engenharia de Produção. Universidade Federal do Paraná - UFPR. Curitiba, Paraná - Brasil. \\ robsonseleme@hotmail.com \\ ${ }^{3}$ Doutora em Engenharia Mecânica. Universidade Federal do Paraná - UFPR. Curitiba, Paraná - Brasil. \\ izabel.zattar@gmail.com \\ ${ }^{4}$ Doutor em Métodos Numéricos em Engenharia. Universidade Federal do Paraná - UFPR. Curitiba, Paraná - Brasil. \\ marquesammarcos@gmail.com \\ ${ }^{5}$ Doutor em Engenharia Mecânica. Universidade Federal do Paraná - UFPR. Curitiba, Paraná - Brasil. \\ fabiano.drozda@gmail.com \\ ${ }^{6}$ Doutora em Métodos Numéricos em Engenharia. Universidade Federal do Paraná - UFPR. Curitiba, Paraná - Brasil. \\ marianakleina11@gmail.com
}

Cite as

American Psychological Association (APA)

Silva, W. de A., Seleme, R., Zattar, I. C., Marques, M. A. M., Drozda, F. O., \& Kleina, M. (2021). Barriers regarding environmental sustainability in civil construction logistics in Curitiba/PR. J. Environ. Manag. \& Sust., 10(1), 1-24, e16148. https://doi.org/10.5585/geas.v10i1.16148.

\begin{abstract}
Objective: This work aimed to identify which are the main barriers that hinder the application of environmental sustainability in the logistics activities of the real estate construction in the city of Curitiba / PR.

Methodology: A content analysis was carried out in the literature that allowed the elaboration of a questionnaire in which the barriers were investigated with specialists in the sector in the city of Curitiba / PR.

Relevance: It is observed that civil construction has a great economic and social impact and a great growth trend is estimated in Brazil, especially concerning real estate construction, due to the demands of housing deficit. Also, civil construction is known to cause a significant negative environmental impact due to its productive and logistical activities, however, considering such aspects there are alternatives such as Reverse Logistics, Green Logistics, and Green Supply Chain Management (GSCM), but that is not usually applied by barriers that inhibit them.

Results: After applying the proposed methodology, it was found that the main barriers to environmental sustainability are the lack of knowledge about sustainability, the lack of management indicators, and the lack of integration between members of the supply chain.
\end{abstract}

Keywords: Civil construction. Reverse logistics. Green logistics. GSCM.

\section{Barreiras à sustentabilidade ambiental na cadeia logística da construção civil de Curitiba/PR}

Resumo

Objetivo: Este trabalho teve por finalidade identificar quais são as principais barreiras que dificultam a aplicação da sustentabilidade ambiental nas atividades logísticas da cadeia da construção civil imobiliária da cidade de Curitiba/PR.

Metodologia: Foi realizada uma análise de conteúdo na literatura que permitiu a elaboração de um questionário em que foram investigadas as barreiras junto a especialistas do setor na cidade de Curitiba/PR.

Relevância: Observa-se que a construção civil tem um grande impacto econômico e social e é 
estimada uma grande tendência de crescimento no Brasil, especialmente com relação à construção imobiliária, devido às demandas de déficit habitacional. Além disso, a construção civil é conhecida por causar um significativo impacto ambiental negativo em virtude das suas atividades produtivas e logísticas, entretanto, considerando tais aspectos existem alternativas como a Logística Reversa, a Logística Verde e a Gestão Verde da Cadeia de Suprimentos (GSCM), mas que costumam não ser aplicadas por barreiras que as inibem.

Resultados: Após aplicação da metodologia proposta, verificou-se que as principais barreiras à sustentabilidade ambiental são a falta de conhecimento sobre sustentabilidade, carência de indicadores de gestão e a ausência de integração entre os membros da cadeia de suprimentos.

Palavras-chave: Construção civil. Logística reversa. Logística verde. GSCM.

\section{Barreras a la sostenibilidad ambiental en la logística de la construcción civil en Curitiba/PR}

\section{Resumen}

Objetivo: Este trabajo tuvo como objetivo identificar cuáles son las principales barreras que dificultan la aplicación de la sustentabilidad ambiental en las actividades logísticas de la construcción inmobiliaria en la ciudad de Curitiba / PR.

Metodología: Luego de una revisión bibliográfica se elaboró un cuestionario en el que se investigaron las barreras con especialistas del sector en la ciudad de Curitiba / PR.

Relevancia: Se observa que la construcción civil tiene un gran impacto económico y social. Se estima una tendencia de crecimiento en Brasil, especialmente en la construcción inmobiliaria, debido a las demandas del déficit habitacional. Asimismo, se sabe que la construcción civil causa un impacto ambiental negativo significativo debido a sus actividades propias del ramo Sin embargo, considerando tales aspectos existen alternativas como la Logística Inversa, la Logística Verde y la Gestión de la Cadena de Suministro Verde (GSCM). Tales alternativas son comúnmente negligenciadas.

Resultados: Luego de aplicar la metodología propuesta, se encontró que las principales barreras para la sustentabilidad ambiental son la falta de conocimiento sobre sustentabilidad, la falta de indicadores de gestión y la falta de integración entre los integrantes de la cadena de suministro.

Palabras-clave: Construcción civil. Logística inversa. Logística verde. GSCM.

\section{Introduction}

In Brazil, civil construction has great economic and social impact because it represents about $6 \%$ of the GDP and provides employment for up to $9 \%$ of the population (CBIC, 2016). Specifically, housing construction in 2015, wherein Brazil had an immediate lack of 6,2 million residential units, characterizing a significant housing deficit (FIESP, 2016). In Paraná state, this lack was 261.675 units for the same year and in Curitiba, the capital of the state, in 2013 the immediate lack was about 70 thousand units. Linked to the housing deficit problems, issues regarding inadequate housing (cohabitation or landholding regularization issues) also exist (IPEA, 2013). Thus, characterizing a demand for housing units in Brazil that can reach about 20 million units in 2024 (FGV, 2014).

According to information summarized in figure 1 , its logistic supply chain presents some unique characteristics when compared to other industries. Such chain starts with the extraction of the raw material from primary sources (1), proceeds for processing industries (2), and ends up at the building site when the construction process occurs (3). After the construction process, the product is finished and it has its specific life cycle (4), then at the 
end, the remodeling processes of deconstruction with the generation of residues may occur (5).

Figure 1 - Civil construction supply chain life cycle

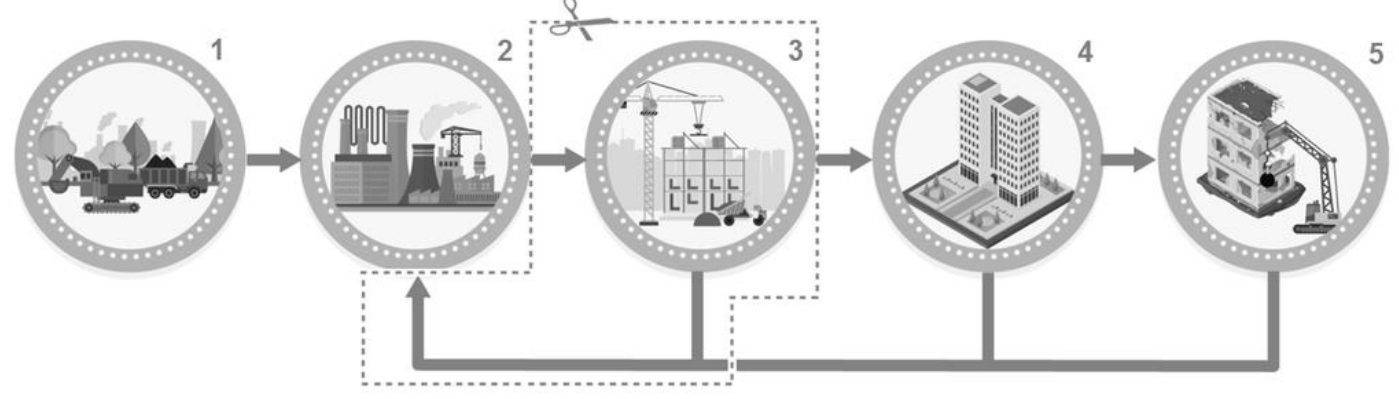

Source: Adapted from (Tavares, 2016).

Thus, it is important to understand that the logistics and productive chain in the civil construction field is known for the capacity to cause impacts to the environment. A great part of the necessary suppliers to the civil work comes from an aggressive extraction that consumes non-renewable natural resources as well as generates residues that can pollute the environment significantly (Paiva \& Ribeiro, 2005).

A despite the demand for using these materials, during the civil work problems related to wastage exist. It is estimated, according to Alexandre \& Saboia (2015), that the average waste can reach $33 \%$ of the available resources during the construction process, specifically, to the generation of solid waste according to the Brazilian Civil Construction and Demolition Residues Recycling Association (Abrecon, 2015), it is calculated that approximately 55\% of all the solid residues in Brazil are proceeding from construction or demolition (about 275 $\mathrm{kg} /$ per hab. / per year).

In consideration of these factors, concerns are raised about the number of natural resources on the planet Earth and concerns regarding the capacity of humanity to keep its continuous growth are raising (Andrade, 2013). Evaluating it from the logistics point of view, the recent literature has pointed to study fields that aim to be a solution for these problems such as Reverse Logistics (RL), Green Logistics (GL), and Green Supply Chain Management (GSCM) (Santos et al., 2015).

However, although alternatives exist, it is frequent in literature the citation of barriers that hinder the full application of these solutions (Jabbour et al., 2013). Thus, the objective of this article is to investigate which are these barriers and verify their intensity level in the housing civil construction context in the city of Curitiba/PR. This evaluation is carried out with the application of a research instrument to specialists. Still, for information only, as for the delimitation, this research approach has only the logistics activities (direct and reverse) that involve the transport of the suppliers to the civil worksite (suppliers on the first level), the 
internal productive activities related to the civil worksite and the eventual reverse transport (FIGURE 1), excluding further activities.

\section{Impacting characteristics of civil construction}

According to Souza (2014), civil construction is the segment that consumes the biggest amount of raw materials and natural resources on the planet and the third one responsible for greenhouse gas emissions to the atmosphere, involving the whole chain that links the materials manufacturers to the final users.

Among all the activities practiced by the human being, the civil construction is one of those which have a major impact in the environment. It's estimated that in Brazil, approximately $40 \%$ of natural resources extraction have the construction industry as a destination. Moreover, up to $50 \%$ of the energy generated in a region is conveyed to supply the functioning of buildings and about $50 \%$ of the urban solid residues come from the constructions and demolitions (Valoto \& Andrade, 2011).

Therefore, civil construction can be considered a key sector for the development and incentive to the sustainability, wherein all the involved parts can modify their processes, leading to a more ecological focus, to revert the picture of the environmental damage and preserve the natural resources for future uses (Ministry of the Environment of Brazil, 2016). But, for it to happen, concepts must be observed in all the stages for the production of enterprises, from projects, execution of the enterprise, to its use and occupation (Souza, 2014).

\section{Sustainable alternatives to logistics:}

Concepts referring to the sustainable alternatives to the logistics, as $R L$ and $G L$, can be confused and be treated as being the same subject, however, such concepts present differences between themselves (Pucci, 2006).

Hierarchically, such concepts can be understood as components of a great field called GSCM (Engelage, Borget \& Souza, 2016), and these aspects are discussed in the items herein.

\section{Reverse Logistics (RL)}

The $R L$ can be understood as the return of used or damaged products from the consumer to the supplier (Fonseca et al., 2015). In the civil construction case, such movement is generally related to the solid residues from construction and demolition. 
Chaves \& Alcântara (2009) define the $\mathrm{RL}$ as the activity responsible for the flow of products coming from the consumer until the origin point, to promote the valuation of the returned goods.

It is observed that $R L$ can function both, in a closed way, when the materials return for some kind of valuation or open when the product or residue is usually discarded effectively (Machado, 2013). In this way, the RL can be considered a method to organize the closing of the logistics cycle (Binoto \& Guarnieri, 2014).

\section{Green Logistics (GL)}

According to Basso Jr. et al. (2016), the GL is concerned about the agreement and minimizing of environmental impacts that can occur in the logistics activities. In this regard, minimizing environmental impacts is the aim, through recycling and remanufacturing, also reducing packaging, natural resources, solid wastes, and pollutants emission, i. e. all production is projected from the sustainability point of view.

Chhabra, Garg, and Singh (2017) corroborate this concept saying that the main objective of the GL is to coordinate the activities within a company in such a way that the customers' requirements are met with the least possible impact on the environment. Thus, the GL comprises the production planning, the management of materials, and its distribution, in order to define strategies that are environment-friendly (Santos et al., 2015).

Among the tools that operationalize the $G L$, the $R L$ can be frequently considered as the only tool for the GL applied in the majority of the organizations which limits the reach towards the most sustainable solutions in its logistics over many circumstances (Barbieri et al., 2014). In figure 2, the relation between $G R$ and $R L$ is verified.

Figure 2 - Relation between Reverse Logistics and Green Logistics

\section{Reverse Logistics}

Green Logistics

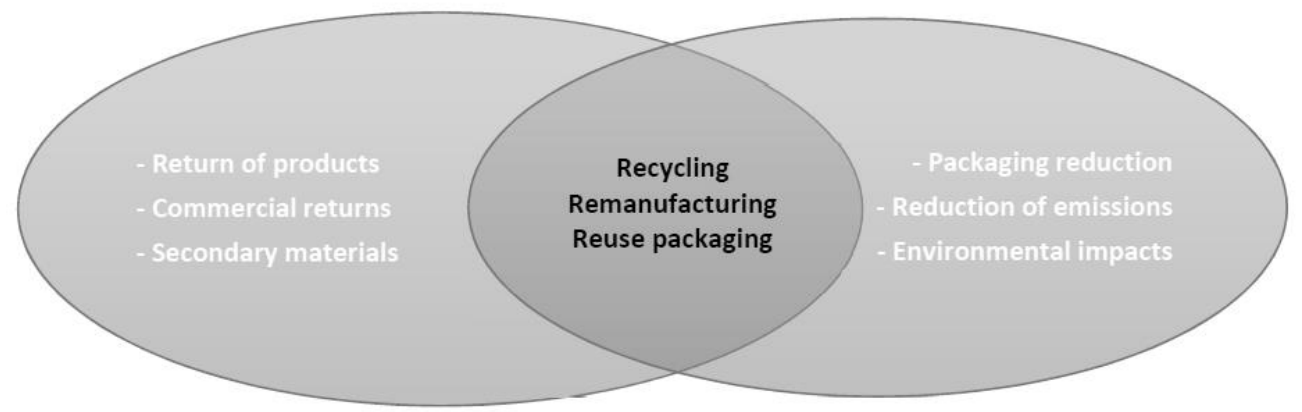

Source: Adapted from (Rogers \& Tibben-Lembke, 1998).

The difference between the two subjects as well as an intersection point: the recycling, remanufacturing, and reuse is observed. 


\section{Green Supply Chain Management (GSCM)}

The definition of the GSCM starts from the premise that the companies function in an integrated manner, as it has occurred in the traditional supplement chain (SCM), however, at this time incorporating the sustainability concepts, mainly the environmental dimension ones (Jabbour et al., 2013). It is about a relatively new concept functioning in an aggregator and multidisciplinary way (Govidan et al., 2014).

The GSCM sprouts from the integration between environment management and the traditional supply chain, aimed at reducing the impacts generated by them and the consequences, such as global heating, several pollutions, as well as of the scarcity of primary resources that can compromise the existence of future generations (Barbieri et al., 2014).

The interest for the GSCM comes from the possible profits of competitiveness that the companies can get. The reduction of risks regarding environmental accidents, better safety conditions for workers, material resources saving, energy, and cleaner production are highlighted (Govidan et al., 2016). Also, an opportunity to improve the corporate image of the companies for their consumers (Franco, 2014). However, the application of the GSCM has occurred on the spot manner, normally pushed by governmental pressures and by the society that searches for less environmental impacts (Binoto \& Guarnieri, 2014).

In conclusion, the comprehension regarding the GSCM starts through the integrated management in several levels of supply and consumption of a supply chain that encompasses the GL and has tool-concepts, such as RL, green marketing, green transport, green load and unload, green packaging, green manufacture/production, green storage, green purchases and green design (Engelage \& Souza, 2016) and also the management of residues according to Dias, Labegalini and Scillag (2012). Figure 3 indicates the subjects which make up the GSCM schematically. 
Figure 3 - Subjects about GSCM Structure

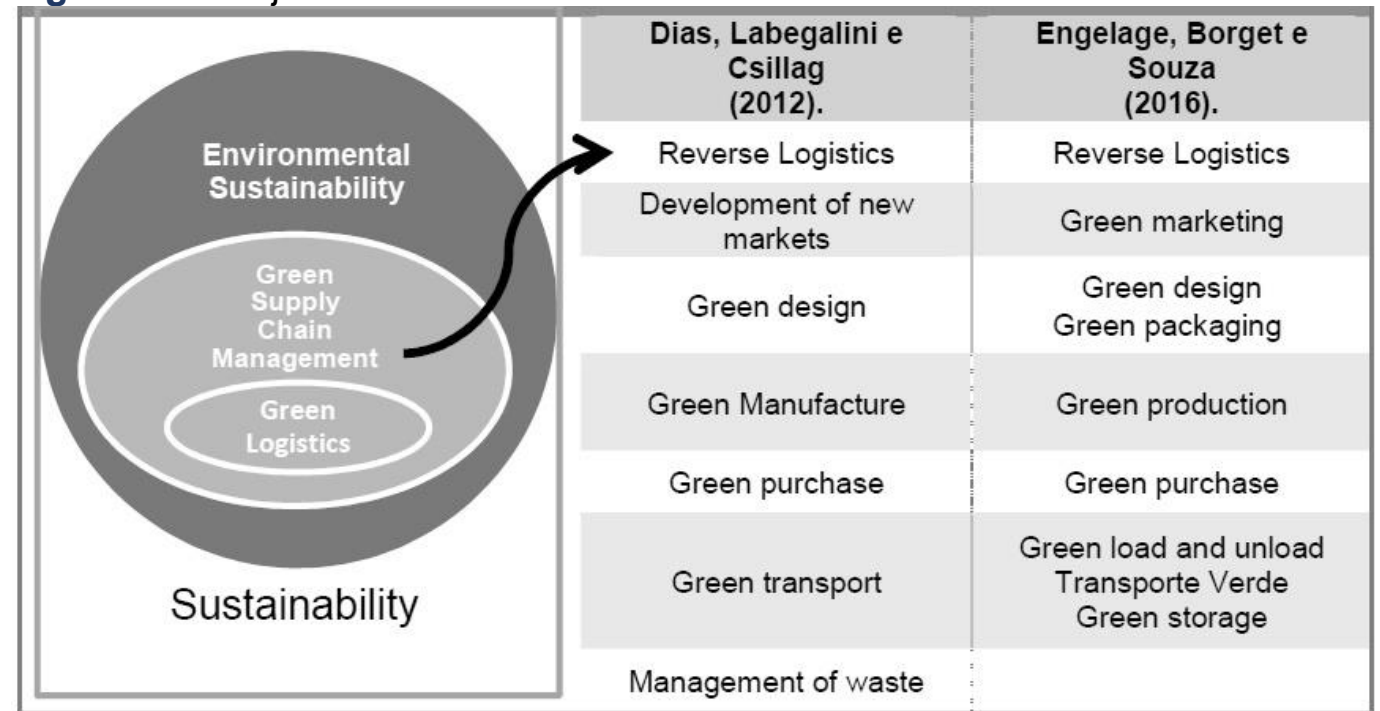

Source: Elaborated by the authors.

According to figure 3 , in the first column one can observe that the $\mathrm{GL}$ is a subject that is inside the great field called GSCM and that the RL is a component subject that helps to operationalize these two areas, also all these subjects are encompassed by the definition of environmental sustainability.

\section{Methodology}

Below the stages used to reach the objective of this article are presented.

\section{Stage 1: information systematization}

In literature, many different excuses hinder the application of sustainable attitudes or tools, and their citation is generally indirect and occurs through referring to negative aspects or occasional difficulties. Thus, to build an obstacles list to the sustainable attitudes for logistics, the Content Analysis technique according to Bardin (2011) was chosen.

To achieve the definitive barriers list research over the Capes Journal Portal was carried out using the term "barriers to GSCM" in English. The reason for choosing Capes Journal Portal came from its comprehensiveness, which comprehends about 39 thousand scientific journal titles, and its capacity of complete availability of the identified articles (Capes, 2017). This research was filtered to get the results from 2011 to 2017, totalizing 25 articles to be analyzed, all in the English language. During the reading of these articles, it was verified that one of them was not very compatible with the research subject, so it was excluded from the sample; two articles related to this study were added to the final sample. They were also identified, through internal citations, this way totalizing 26 articles. 
Following the Content Analysis, the information was organized in a spreadsheet, and using affinity categorization, this information was grouped until reaching the number of 20 barriers.

Afterward, the barriers list was used for building the research instrument (questionnaire) that was applied in partnership with specialists of the civil construction sector from Curitiba/PR.

\section{Stage 2: building the research instrument}

The questionnaire was chosen as a research instrument due to the advantages presented by Marconi \& Lakatos (2010) who affirm that this technique is useful for agility, easiness of access to the public, and for propitiating the anonymity to the respondents preventing the influence of the researcher bias.

The objective of this research instrument was to verify the adherence and the barriers intensity level found in literature, in the scenario of the civil construction in Curitiba/PR in the real estate sector in partnership with two distinct groups (civil engineering professionals and teaching professionals of this area).

According to what Bouzon et al. (2016) said, it is convenient to reflect on the impossibility to resolve all the problems at the same time and therefore the importance of identifying the most critical items, so that these would be the ones to be having attention focus.

To accomplish it, the 20 items listed in the literature were transformed into a questionnaire using a Likert scale of five alternatives. Each reply had a score: Strongly disagree; Disagree; Neither agree nor disagree; Agree; Strongly agree.

Until it reached the definitive format, the questionnaire was validated with a reduced sample of four participants - a professor and three professionals. In this pilot test carried out in August 2017, the questionnaire was verified concerning the writing of the questions and organization of the information.

\section{Stage 3: characterizing the participants}

For selecting the public who answered the questionnaire, two groups were defined:

1st Group: teaching professionals who teach civil engineering subjects in Curitiba/PR. This group was chosen because the professors are responsible for the formation of the civil engineering professionals and are a group connected to the cutting-edge researches that generally anticipate the innovations of the market. For identifying the respondent potentials of this group, 11 universities and colleges websites in the city 
that offer the civil engineering undergraduate course were checked, then the email contacts of 131 teaching professionals were identified.

2nd Group: professionals formed in civil engineering and that were directly connected to the building productive process with housing purpose in the city of Curitiba/PR. The choice for this group was motivated by the fact that these professionals are directly influenced by the barriers identified in the literature. For obtaining the contacts, the social media website Linkedln was used, wherein professionals that met the initial requirements were filtered and invited to be part of the network of the first author of this article. Through this procedure 464, email and/or telephone contacts were reached.

\section{Stage 4: data collection}

The data collection was organized during the period between September 13, 2017, until November 15, 2017. To reach the teaching professionals the contact was completely carried out by email. While for the civil engineers, the contact was carried out primarily through email and by telephone whenever it was possible.

Thus, after presenting and clarifying the academic purposes and confidential data protection the form was sent to be filled online. The Google Forms ${ }^{\circledR}$ tool was used for this task.

The following results were obtained: Teachers: 131 emails sent, with 25 complete answers and 19,08\% return rate. Engineers: 464 emails sent, with 102 answers and a $21,98 \%$ return rate. For the second group case, 14 answers were identified and did not meet the target of the research - the professional either was not acting in the real estate construction field or was forwarded by a third party to people who are not able to answer. These were excluded from the sampling. It is observed that the average rate of the answers is close to the values identified in similar studies, as Govidan et al. (2014), Teixeira et al. (2016), and Sheu (2015) that obtained an average of $27.09 \%$ of the answers about the questionnaires sent.

In consideration, for analyzing the data, 25 answers from the teachers and 88 answers from the engineering professionals were used, comprising a total sample of 113 answers. 


\section{Results and discussion}

\section{Barriers to the environmental sustainability in the logistics}

Through Content Analysis and information classification, a list with the main items related as barriers to the environmental sustainability in the logistics activities was obtained. Such information is summarized below:

B01 Lack of qualified manpower: the low qualification of the manpower affects the decision-making in the organizations and delays the implementation of green alternatives and it is also a factor that influences the resistance to changes and innovation, in the lack of engagement/participation and it is a reason for low productivity (Muduli et al., 2013; Barve \& Muduli, 2013; Mathiyazhagan et al., 2013; Govidan et al., 2014; Lee et al., 2014; Mathiyazhagan et al., 2015; Hussain, Awasthi \& Tiwari, 2016; Balon, Sharna \& Barua, 2016; Teixeira et al., 2016; Rehman, Seth \& Shrivastava, 2016; Bouzon et al., 2016; Govidan et al., 2016; Wang et al., 2016; Raut, Narkhede \& Gardas, 2017).

B02 Lack of developing suppliers: the difficulty regarding developing suppliers is related to the green purchases, therefore the must develop suppliers that have the same commitment to greens and sustainable practices as the main organization. Moreover, the difficulty in managing the great number of suppliers and their sublevels exists, therefore it is necessary for the supplier of its supplier to be equally sustainable (Barve \& Muduli, 2013; Mathiyazhagan et al., 2013; Lee et al., 2014; Govidan et al., 2014; Jabbour, Frascareli \& Jabbour, 2015; Jakhar, 2015; Rauer \& Whu, 2015; Rehman, Seth \& Shrivastava, 2016; Woo et al., 2016; Woo et al., 2016; Wang et al., 2016; Wu \& Barnes, 2016; Balon, Sharna \& Barua, 2016; Teixeira et al., 2016; Geng et al., 2017). B03 Lack of governmental support: the lack of governmental support intervenes in situations such as the absence of coherent, conscientious, and fair laws, the absence of supervision of the imposed laws, the absence of tax or economic incentives (loan for green alternatives) programs and, in the aspects of politics conduction, when the governments are capable to generate uncertainties to the society as the bureaucracy and the corruption. Furthermore, the governments generally supply the infrastructure conditions which propitiate the conduction of the logistics activities (Barve \& Muduli, 2013; Muduli et al., 2013; Mathiyazhagan et al., 2013; Govidan et al., 2014; Lee et al., 2014; Ojo, Mbowa \& Akinlabi, 2014; Shen, Muduli \& Barve, 2015; Rauer \& Whu, 2015; Jakhar, 2015; Hussain, Awasthi \& Tiwari, 2016; Bouzon et al., 2016; Govidan et al., 2016; Wang et al., 2016; Rehman, Seth \& Shrivastava, 2016; Balon, Sharna \& Barua, 2016; Raut, Narkhede \& Gardas, 2017; Geng et al., 2017). 
B04 Lack of knowledge on sustainable practices: the lack of knowledge on sustainable practices can take place due to the lack of studies referring to the subject (mainly in the developing countries), the recent aspect of the subjects related to sustainable alternatives, the lack of consensus about the best practices, as well as the unfamiliarity in the organizations about the advantages and disadvantages of green alternatives, cause difficulty for the decision taking (Barve \& Muduli, 2013; Muduli et al., 2013; Mathiyazhagan et al., 2013; Govidan et al., 2014; Jabbour, Frascareli \& Jabbour, 2015; Jakhar, 2015; Mathiyazhagan et al., 2015; Rehman, Seth \& Shrivastava, 2016; Bouzon et al., 2016; Woo et al., 2016; Wang et al., 2016; Geng et al., 2017; Sari, 2017).

B05 Lack of environmental awareness of the consumers: the lack of awareness, especially regarding the environmental impacts and the limited amount of natural resources is cited as a reason which makes the companies delay the investment in green and sustainable alternatives, justifying that the consumers do not make the judgment of the advantages that it represents, furthermore, the consumers are not always willing to pay more for the products. Another point is about the existence of investment, but in the function of the ignorance concerning the impacts, the population ends up not making the correct use of the sustainable alternatives (Muduli et al., 2013; Barve \& Muduli, 2013; Mathiyazhagan et al., 2013; Govidan et al., 2014; Ojo, Mbowa \& Akinlabi, 2014; Hussain, Awasthi \& Tiwari, 2016; Wang et al., 2016; Rehman, Seth \& Shrivastava, 2016; Bouzon et al., 2016; Govidan et al., 2016; Raut, Narkhede \& Gardas, 2017).

B06 Lack of new technologies, materials and processes implementation: the lack of new technologies, materials, and processes implementation is a consequence of the priority for traditional production methods, some obsolete, less productive, which generate waste and more pollution, but chosen by the majority of the companies because it is cheaper (Muduli et al., 2013; Barve \& Muduli, 2013; Mathiyazhagan et al., 2013; Govidan et al., 2014; Shen, Muduli \& Barve, 2015; Jakhar, 2015; Wang et al., 2016; Balon, Sharna \& Barua, 2016; Bouzon et al., 2016; Rehman, Seth \& Shrivastava, 2016; Raut, Narkhede \& Gardas, 2017).

B07 Lack of sustainability indicators usage: the lack of sustainability indicators is seen as a barrier because without measuring properly their level of implementation the organization cannot have guidance on their evolution, not to mention the difficulties for their processes monitoring and control (Mathiyazhagan et al., 2013; Govidan et al., 2014; Jia, Diabat \& Mathiyazhagan, 2015; Shen, Muduli \& Barve, 2015; Jabbour, Frascareli \& Jabbour, 2015; Balon, Sharna \& Barua, 2016; Bouzon et al., 2016; Woo et al., 2016; Raut, Narkhede \& Gardas, 2017). 
B08 Lack of integration between the members of the supply chains: the lack of integration and systemic vision between the members of the supply chains can directly intervene towards more sustainable logistics, such fact is verified by the full necessity of communication among the members of the chain, with transparency and reliability. Among these members, the suppliers, transporters, and distributors are highlighted (Govidan et al., 2014; Ojo, Mbowa \& Akinlabi, 2014; Sheu, 2015; Hussain, Awasthi \& Tiwari, 2016; Rauer \& Whu, 2015; Jabbour, Frascareli \& Jabbour, 2015; Mathiyazhagan et al., 2015; Balon, Sharna \& Barua, 2016; Rehman, Seth \& Shrivastava, 2016; Teixeira et al., 2016; Bouzon et al., 2016; Raut, Narkhede \& Gardas, 2017; Geng et al., 2017).

B09 Lack of transport infrastructure: the lack of transport infrastructure can affect the level of sustainable practices implementation as it limits the number of possibilities for decisions (Muduli et al., 2013; Wu \& Barnes, 2016; Bouzon et al., 2016).

B10 Lack of demand for green and sustainable products: the uncertainty regarding the existence of demand for the green products is reasonable because the lack of certainty concerning the commercialization of the products makes the companies prevent the investments, causing another issue that is the difficulty to forecast demand (Ojo, Mbowa \& Akinlabi, 2014; Balon, Sharna \& Barua, 2016; Bouzon et al., 2016).

B11 Complexity in the development of a green product project: for adjusting the production to guarantee results that are balanced with the environment, there is a demand for developing the product project. However, some companies claim that the process of planning green products is more complex, longer, and more expensive (Muduli et al., 2013; Jabbour, Frascareli \& Jabbour, 2015; Mathiyazhagan et al., 2015; Rauer \& Whu, 2015; Wang et al., 2016; Rehman, Seth \& Shrivastava, 2016; Raut, Narkhede \& Gardas, 2017).

B12 Lack of top management engagement: the green alternatives can be influenced by the organizations high management commitment or interest level to implement them. The high management can define aspects as mission and vision and determine the company engagement level regarding sustainable practices. But, in certain cases the resistance of the high management to invest in green alternatives can occur, either because they prefer to prioritize other aspects as the financial or because they are unaware of the advantages of these alternatives (Muduli et al., 2013; Barve \& Muduli, 2013; Mathiyazhagan et al., 2013; Govidan et al., 2014; Ojo, Mbowa \& Akinlabi, 2014; Mathiyazhagan et al., 2015; Shen, Muduli \& Barve, 2015; Jakhar, 2015; Balon, Sharna \& Barua, 2016; Teixeira et al., 2016; Rehman, Seth \& Shrivastava, 2016; Bouzon et al., 2016; Govidan et al., 2016; Woo et al., 2016; Wang et al., 2016; Raut, Narkhede \& Gardas, 2017; Geng et al., 2017). 
B13 Difficulties with the competition: the difficulties regarding the competitors can become a problem when certain competitors are disloyal in the intention to cheap their costs (illegally disposing residues or acting in the informality), also, the rising competition scenario between the companies who fight for markets and costs reduction (Mathiyazhagan et al., 2015; Raut, Narkhede \& Gardas, 2017).

B14 Lack of planning for applying green practices: the difficulties for implementing the green alternatives are reasoned by the change and greater complexity due to the adaptation in the organizational aspects that will take longer and due to the fast pace wherein technological changes occur making the decisions making difficult (Barve \& Muduli, 2013; Mathiyazhagan et al., 2013; Govidan et al., 2014; Jia, Diabat \& Mathiyazhagan, 2015; Jabbour, Frascareli \& Jabbour, 2015; Jakhar, 2015; Shen, Muduli \& Barve, 2015; Bouzon et al., 2016; Teixeira et al., 2016; Wu \& Barnes, 2016; Woo et al., 2016; Geng et al., 2017).

B15 Lack of financial resources: the cost for implementing green alternatives has been discussed and needs a bigger initial investment, this cost is added to the sales price. In some points, this is consensual, such as the cost for disposal of dangerous materials, $\mathrm{RL}$ implementation guarantee, and use of more efficient and less polluting technologies. Moreover, commonly companies focus on their financial sustainability, securing shortterm profits and benefits and not always prioritizing the environmental issues (Mathiyazhagan \& Haq, 2013; Muduli et al., 2013; Barve \& Muduli, 2013; Mathiyazhagan et al., 2013; Govidan et al., 2014; Ojo, Mbowa \& Akinlabi, 2014; Sheu, 2015; Jakhar, 2015; Wang et al., 2016; Balon, Sharna \& Barua, 2016; Teixeira et al., 2016; Rehman, Seth \& Shrivastava, 2016; Bouzon et al., 2016; Woo et al., 2016; Raut, Narkhede \& Gardas, 2017; Geng et al., 2017).

B16 Difficulty with several stakeholders: managing the stakeholders (non-governmental organizations, governments, media, competitors, and mainly the consumers) is a challenge, because these parts may present specific pressures and demands making the sustainable alternatives management process difficult. Also, the communication problems and noises that can occur with all these components of the productive chain (Mathiyazhagan \& Haq, 2013; Muduli et al., 2013; Barve \& Muduli, 2013; Govidan et al., 2014; Lee et al., 2014; Mathiyazhagan et al., 2015; Shen, Muduli \& Barve, 2015; Sheu, 2015; Jabbour, Frascareli \& Jabbour, 2015; Bouzon et al., 2016; Teixeira et al., 2016; Rehman, Seth \& Shrivastava, 2016; Woo et al., 2016; Raut, Narkhede \& Gardas, 2017). B17 Fear of failure: the fear of failure comes from the uncertainties regarding the market and the distrust on taking risks regarding new technologies (Mathiyazhagan et al., 2013; Govidan et al., 2014; Lee et al., 2014; Wang et al., 2016; Raut, Narkhede \& Gardas, 2017). 
B18 Influence of the organization size in the application of the sustainable practices: the size of the organization can influence the sustainable application practices level, indicating that small and medium-size companies have more difficulty adapting to these practices. It could be a reason for the low number of companies that embrace such movement (Mathiyazhagan \& Haq, 2013; Govidan et al., 2014; Lee et al., 2014; Woo et al., 2016; Govidan et al., 2016; Raut, Narkhede \& Gardas, 2017).

B19 Lack of engagement in all the organization levels: the lack of engagement in all the levels of an organization (board of directors, management, and production) causes difficulty for managing and integrating towards a more sustainable production (Jia, Diabat \& Mathiyazhagan, 2015; Mathiyazhagan et al., 2015; Jabbour, Frascareli \& Jabbour, 2015; Rehman, Seth \& Shrivastava, 2016; Geng et al., 2017).

B20 Lack of implementing the reverse logistics: it has been found that some organizations still do not fully apply $R L$, either because they prioritize the direct distribution or because they have difficulties on managing and treating their residues (Jia, Diabat \& Mathiyazhagan, 2015; Balon, Sharna \& Barua, 2016; Rehman, Seth \& Shrivastava, 2016; Bouzon et al., 2016; Wang et al., 2016; Raut, Narkhede \& Gardas, 2017).

To finish with the classification of the items that make the logistics environmental sustainability implementation difficult, according to literature, they were sorted out in internal and external to organizations, as realized by Souza (2013). Such classification is represented in figure 4.

Figure 4 - Classified Barriers among internal and external aspects

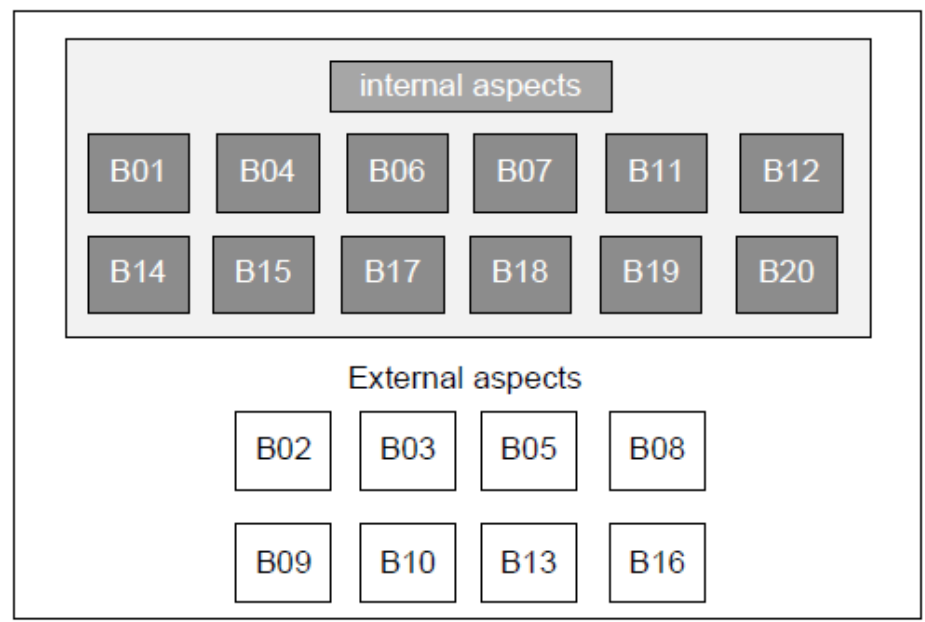

Source: Elaborated by the authors.

The classification displayed in figure 4 is convenient, as the internal aspects can be actively executed by the companies, whereas concerning external, the organizations are more reliant on other interesting parts (stakeholders) (Geng et al., 2017). 


\section{Consistency of the research instrument}

In the intention to evaluate the consistency of the answers, the Cronbach's Alpha index was calculated, which has as objective to point out the answers of the questionnaire that bring some reliability. Such indicator is calculated due to the number of items (questions) of the questionnaire and the variances of each answer set also the total variance observed. The result obtained through this study was 0,860 , meaning a good and substantial number according to Hair et al. (2005). Below the main discoveries concerning the applied questionnaire are presented.

\section{Presenting the respondents groups: professors}

Referring to the sample of 25 teaching professionals from Curitiba who answered the research instrument, $96 \%$ have are university graduates at master's level of and/or above, and $60 \%$ of the sample was comprised of teachers with five years or more of lecturing on the subject, as table 1 describes.

\begin{tabular}{|c|c|c|}
\hline Question & Answer & (\%) \\
\hline \multicolumn{3}{|c|}{ Academic qualification } \\
\hline Specialization & 1 & $4 \%$ \\
\hline Master degree & 12 & $48 \%$ \\
\hline Doctorate degree & 10 & $40 \%$ \\
\hline Post-doctoral & 2 & $8 \%$ \\
\hline Total & 25 & $100 \%$ \\
\hline \multicolumn{3}{|l|}{ Experience (years) } \\
\hline 0 a 5 & 10 & $40,0 \%$ \\
\hline 5 a 10 & 2 & $8,0 \%$ \\
\hline 10 a 20 & 7 & $28,0 \%$ \\
\hline More of 20 & 6 & $24,0 \%$ \\
\hline Total & 25 & $100 \%$ \\
\hline
\end{tabular}

Moreover, 11 of these teachers teach subjects related to the research subjects (transports, logistics, environment, and sustainability).

Presenting the respondents groups: civil engineers

Regarding the 88 civil engineers sample, it was verified that more than half $(52.3 \%)$ of the respondents have a post-graduation degree on specialization level (43) and master's degree (3), and about $70 \%$ of the sample is comprised of professionals with more than 5 years of professional experience (TABLE 2). 
Table 2 - Sample of engineering professionals

\begin{tabular}{|c|c|c|}
\hline Question & Answer & (\%) \\
\hline \multicolumn{3}{|l|}{ Post-graduation } \\
\hline Yes & 46 & $52,3 \%$ \\
\hline No & 42 & $47,7 \%$ \\
\hline $\begin{array}{l}\text { Total } \\
\text { Experience (years) }\end{array}$ & 88 & $100 \%$ \\
\hline 0 a 5 & 27 & $30,7 \%$ \\
\hline 5 a 10 & 33 & $37,5 \%$ \\
\hline 10 a 20 & 18 & $20,5 \%$ \\
\hline More of 20 & 10 & $11,4 \%$ \\
\hline Total & 88 & $100 \%$ \\
\hline
\end{tabular}

When asked concerning the main subjects for this study, it was verified that the professionals of this sample present some knowledge concerning the $\mathrm{RL}$ (69.3\%), but little knowledge on GL and GSCM (on average $32.35 \%$ knew the subject) (TABLE 3).

Table 3. - Classification of the professionals regarding the level of knowledge about the subjects

\begin{tabular}{lcc}
\hline Question & Answer & $(\%)$ \\
\hline Knowledge about RL & & \\
Yes & 61 & $69,3 \%$ \\
No & 27 & $30,7 \%$ \\
Total & $\mathbf{8 8}$ & $\mathbf{1 0 0} \%$ \\
Knowledge about GL & & \\
Yes & 31 & $35,2 \%$ \\
No & 57 & $64,8 \%$ \\
Total & $\mathbf{8 8}$ & $\mathbf{1 0 0} \%$ \\
Knowledge about GSCM & & \\
Yes & 26 & $29,5 \%$ \\
No & 62 & $70,5 \%$ \\
Total & $\mathbf{8 8}$ & $\mathbf{1 0 0} \%$ \\
\hline
\end{tabular}

Source: Elaborated by the authors.

The low level of positive answers concerned the GL and GSCM, can be due to the novelty of the subject, which has had more significant results in the literature from the $2000 \mathrm{~s}$ (Silva; Seleme \& Silva, 2017).

Regarding the companies for which the professionals of this sample work, it was verified that about $75 \%$ of the professionals are engaged with companies from Curitiba/PR, half of them with more than 10 years of acting in the market. About $70 \%$ of the professionals act in small companies classified as micro or small enterprises, according to SEBRAE 
(Brazilian Micro and Small Business Support Service) (Sebrae, 2013) criteria, which indicates that companies of the industry with up to 99 employees belong to these sizes.

Regarding the customer profile who is served by these constructors, it was found that only $4.5 \%$ of the engineers of this sample work with the public from the social classes $D$ and $\mathrm{E}$, exactly the ones in more need of housing according to the Brazilian housing deficit (FGV, 2014) (TABLE 4).

Table 4 - Classification of companies linked to the sample

\begin{tabular}{lll}
\hline Question & Answer & $(\%)$ \\
\hline $\begin{array}{l}\text { Origin of the company at work } \\
\text { Curitiba }\end{array}$ & 65 & $73,9 \%$ \\
Other cities & 23 & $26,1 \%$ \\
Total & $\mathbf{8 8}$ & $\mathbf{1 0 0 \%}$ \\
Time of the company in the market (years) & & \\
0 a 5 & 25 & $28,4 \%$ \\
5 a 10 & 18 & $20,5 \%$ \\
10 a 20 & 13 & $14,8 \%$ \\
more of 20 & 32 & $36,4 \%$ \\
Total & 88 & $100 \%$ \\
Number of employees & & \\
Until 19 & 37 & $42,0 \%$ \\
from 20 to 99 & 24 & $27,3 \%$ \\
from 100 a 499 & 12 & $13,6 \%$ \\
more of 500 & 15 & $17,0 \%$ \\
Total & 88 & $\mathbf{1 0 0} \%$ \\
Customer profile & & \\
Classes A e B & 54 & $61,4 \%$ \\
Class C & 30 & $34,1 \%$ \\
Classes D e E & 4 & $4,5 \%$ \\
Total & $\mathbf{8 8}$ & $\mathbf{1 0 0} \%$ \\
\hline Source: Elaborated by the authors. & &
\end{tabular}

The results obtained through this sample referring to the barriers considered as critical for the success of environmental sustainability are presented below.

\section{Descriptive statistics of the collected data}

According to the Likert scale adopted for the questionnaire, values higher than three and up to five showed agreement with the fact wherein that item is hampering the application of environmental sustainability in the logistic chain in the city of Curitiba.

The initial analysis, through descriptive statistics, as table 5, points that all the barriers, for both groups (teachers and civil engineers), presented an average score higher than three (indicating acceptance of the item as a barrier), the only exception was the B06 
barrier for the teacher's group whose average was 2,68. Another discovery is referring to the Standard Deviation values (SD), which are mostly higher than one (16 items in each SD group $>1$ ). Such fact can be a consequence of a small sampling size and highlights larger dispersion of the achieved results.

Table 5 - Sampling average and standard deviation

\begin{tabular}{|c|c|c|c|c|c|c|}
\hline \multirow{2}{*}{ BARRIERS } & \multicolumn{2}{|l|}{ Professors } & \multicolumn{2}{|c|}{ Engineers } & \multicolumn{2}{|c|}{ Total sample } \\
\hline & Average & (SD) & Average & (SD) & Average & (SD) \\
\hline B01 qualified manpower & 4,12 & $(1,05)$ & 3,75 & $(1,22)$ & 3,83 & $(1,19)$ \\
\hline B02 developing suppliers & 3,84 & $(0,85)$ & 3,86 & $(0,90)$ & 3,86 & $(0,89)$ \\
\hline B03 governmental support & 4,00 & $(1,08)$ & 3,90 & $(1,19)$ & 3,92 & $(1,17)$ \\
\hline B04 knowledge on sustainable practices & 3,92 & $(1,08)$ & 4,28 & $(0,87)$ & 4,20 & $(0,93)$ \\
\hline B05 environmental awareness of the consumers & 3,84 & $(1,14)$ & 3,88 & $(1,15)$ & 3,87 & $(1,15)$ \\
\hline B06 new technologies, materials, and processes & 2,68 & $(1,11)$ & 3,15 & $(1,32)$ & 3,04 & $(1,28)$ \\
\hline B07 sustainability indicators usage & 4,12 & $(0,97)$ & 3,92 & $(1,00)$ & 3,96 & $(0,99)$ \\
\hline B08 integration between supply chain members & 4,04 & $(0,89)$ & 3,92 & $(1,05)$ & 3,95 & $(1,02)$ \\
\hline B09 transport infrastructure & 3,68 & $(1,25)$ & 3,49 & $(1,27)$ & 3,53 & $(1,26)$ \\
\hline B10 demand for green products & 3,12 & $(1,17)$ & 3,45 & $(1,25)$ & 3,38 & $(1,23)$ \\
\hline B11 complexity to development project product & 3,04 & $(1,10)$ & 3,39 & $(1,08)$ & 3,31 & $(1,09)$ \\
\hline B12 top management engagement & 3,88 & $(1,01)$ & 3,84 & $(1,16)$ & 3,85 & $(1,13)$ \\
\hline B13 difficulties with competitors & 3,20 & $(1,19)$ & 3,59 & $(1,23)$ & 3,50 & $(1,23)$ \\
\hline B14 planning to green practices & 3,72 & $(1,21)$ & 4,03 & $(0,98)$ & 3,96 & $(1,03)$ \\
\hline B15 financial resources & 3,52 & $(1,12)$ & 3,63 & $(1,31)$ & 3,60 & $(1,26)$ \\
\hline B16 difficulties with stakeholders & 3,36 & $(1,15)$ & 3,69 & $(1,09)$ & 3,62 & $(1,10)$ \\
\hline B17 fear of failure & 3,04 & $(1,21)$ & 3,36 & $(1,37)$ & 3,29 & $(1,34)$ \\
\hline B18 organization size & 3,28 & $(1,21)$ & 3,28 & $(1,41)$ & 3,28 & $(1,36)$ \\
\hline B19 enqaaement oraanization levels & 3.60 & $(1,19)$ & 3,85 & $(1,16)$ & 3,80 & $(1,17)$ \\
\hline B20 implementing the reverse logistics & 3,48 & $(0,87)$ & 3,74 & $(1,17)$ & 3,68 & $(1,11)$ \\
\hline
\end{tabular}

Source: Elaborated by the authors

Still, in table 5, the differentiation adopted in the revision of the literature (internal and external aspects) is observed. In this case, the underlined item is referring to the internal barriers to the organization.

When comparing the average values in decreasing order and plotting the graph separating the internal and external aspects, figure 5 is achieved.

Figure 5 - Classified Barriers versus Sampling Averages in a decreasing order

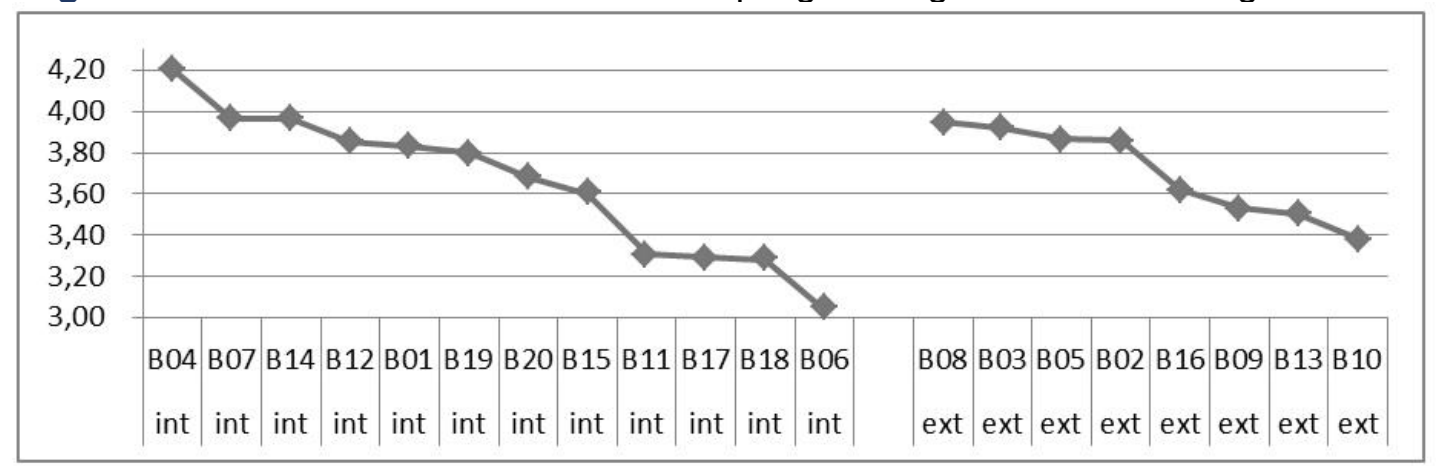

Source: Elaborated by the authors. 
Through figure 5, it is observed that between the internal aspects the barriers 04, 07 , 14 are the most critical ones, while for the external aspects, the barriers 08, 03, 05 are the most critical ones.

Regarding the low average barriers, concerning the external aspects, the ones that obtained the lowest average were B09, B13 and B10. Regarding the internal aspects, the average value of 3,04 for the B06 (New technologies, materials, and processes) was a surprise, possibly indicating that the professionals in Curitiba do not perceive such items as a significant problem.

\section{Conclusions}

The objective of this article was to investigate the barriers for applying the environmental sustainability in the logistics of civil construction in the real estate field, and verifying its intensity level in Curitiba/PR context.

In order to do that, literature content was analyzed and issues regarding the potential barriers were identified. These items were classified and sorted into internal and external aspects to the organizations, considering the fact that the companies have greater strength to apply the necessary changes through management actions. At the end of this process 20 items considered as barriers were listed, wherein 12 were associated to internal aspects and 8 to external aspects.

Based on this list, research instrument was developed and it sought to explore the topic together with specialists of the city. Thus, it was found that the most critical items tend to be: lack of knowledge concerning sustainable practices (B04), the lack of indicators for green management (B07) and the lack of integration between the components of the supply chain (B08).

Considering these barriers, opportunities for future work can be perceived, such as questioning the role of the local public power as a catalyst for sustainable policies and also exploring aspects related to the main certifications of sustainable buildings, as cited by Silva (2019): Leadership in Energy and Environmental Design (LEED), Building Research Establishment Environmental Assessment Method (BREEAM), High Environmental Quality (AQUA) and Brazilian certification Selo Casa Azul. Through these certifications, an investigation can be carried out to map and understand how adherence to each can contribute to the process of reducing impacts on the civil construction logistics chain in Curitiba / PR.

Also, for future work, considering the collected data, it is recommended to expand the research using multicriteria analysis methods such as Analytic Hierarchy Process (AHP), 
Interpretive Structural Modeling (ISM), or Structural Equation Modeling (SEM) and from the application of these techniques better assess the intensity level of each listed barrier.

\section{References}

Alexandre, A. C., \& Saboia, J. (2015). A motivação e seu impacto no desperdício de recursos em uma empresa da construção civil de Porto Alegre/RS. Update, v. 2, n. 1, p. 420.

Bardin, L. (2011). Análise de conteúdo. Edições 70. São Paulo. Brasil.

Basso Júnior, A. F., Rodrigues, E. R., Triches, J., da Silva, J. R. C. S., Welchen, V., Ganzer, P. P., \& Olea, P. M. M. (2016). Green Logistics e Green Marketing como Práticas Sustentáveis. Sustainable Business International Journal, (63).

Abrecon - Associação Brasileira para Reciclagem de Resíduos da Construção Civil e Demolição. (2015). Relatório Pesquisa Setorial 2014/2015. Available at: http://www.abrecon.org.br/relatorio-pesquisa-setorial-20142015/. Accessed 17 jan. 2017.

Andrade, D. B. (2013). Indicadores de sustentabilidade para a produção arquitetônica atual. Revista Especialize On-line IPOG, Goiânia, v.1. n. 6.

Balon, V.; Sharna, A. K.; Barua, M. K. (2016). Assessment of Barriers in Green Supply Chain Management Using ISM: A Case Study of the Automobile Industry in India. Global Business Review, p. 116-135. http://journals.sagepub.com/doi/10.1177/0972150915610701.

Barbieri, J. C., Souza Filho, J. M. de, Brandão, C. N., Serio, L. C. D., Reyes Jr., \& E. Green Supply Chain Management: Analysis Of Brazilian Academic Publications (2014). Revista Produção online, v. 14, n. 3, p. 1104-1128, jul./set. https://doi.org/10.14488/16761901.v14i3.1674.

Barve, A., \& Muduli, K. (2013). Modelling the challenges of green supply chain management practices in Indian mining industries. Journal of Manufacturing Technology Management, v. 24, n. 8, p. 1102-1122. https://doi.org/10.1108/JMTM-09-2011-0087.

Binoto, R., \& Guarnieri, P. (2014). Inovação Logística na Gestão das Cadeias de Suprimentos. In: Christian Julius Folz; Fábio Henrique Trovon de Carvalho. (org.). Ecossistema Inovação, Embrapa, Brasília. Available at: https://www.embrapa.br/instrumentacao/busca-de-publicacoes//publicacao/1001206/ecossistema-inovacao. Accessed 14 jan. 2017.

Bouzon, M., Govidan, K., Rodriguez, C. M. T., \& Campos, M. S. L. (2016). Identification and analysis of reverse logistics barriers using fuzzyDelphi method and AHP. Resources, Conservation and Recycling, 108, p. 182-197. https://doi.org/10.1016/j.resconrec.2015.05.021.

Capes - Coordenação de Aperfeiçoamento de Pessoal de Nível Superior. (2017). Portal de Periódicos CAPES/MEC, 2017. Available at: http://www-periodicos-capes-govbr.ez22.periodicos.capes.gov.br/?option=com_pnews\&component=NewsShow\&view=pne wsnewsshow\&cid=543\&mn=71. Accessed 28 de feb. 2017. 
Cbic - Câmara Brasileira da Indústria da Construção. (2016). PIB 2015. Available at: http://www.cbicdados.com.br/menu/home/pib-2015. Accessed 02 jan. 2017.

Chaves, G. de L. D., \& Alcântara, R. L. C. (2019). Logística Reversa: uma análise da evolução do tema através de uma revisão da literatura. XXIX Encontro Nacional de Engenharia de Produção, Salvador, Brasil.

Chhabra, D.; Garg, S. K.; Singh R. K. (2017). Analyzing alternatives for green logistics in an indian automotive organization: a case study. Journal of Cleaner Production, 167, p. 962 969. https://doi.org/10.1016/j.jclepro.2017.02.158.

Dias, S. L. F. G.; Labegalini, L.; Csillag, J. M. (2012). Sustainability in supply chains: a comparative perspective in domestic and international journals. Produção, São Paulo, v.22, n.3, p. 517-533. http://dx.doi.org/10.1590/S0103-65132012005000034.

Engelage, E.; Borget A.; Souza, M. A. (2016). Green Logistic Practices: A Theoretical Approach Of The Theme. Revista de Gestão Ambiental e Sustentabilidade - GeAS, v.5, n.3, setembro/dezembro. DOI: 10.5585/geas.v5i3.446

Fgv Projetos. (2014). Políticas permanentes de habitação - A importância do programa minha casa minha vida, outubro. Available at:

http://www.cbic.org.br/migracao/sites/default/files/Estudo\%20FGV\%20-\%20MCMV_1.pdf. Accessed 15 jan. 2017.

Fiesp - Federação das Indústrias do Estado de São Paulo. (2016). Levantamento inédito mostra déficit de 6,2 milhões de moradias no Brasil. Available at: http://www.fiesp.com.br/noticias/levantamento-inedito-mostra-deficit-de-62-milhoes-demoradias-no-brasil/. Accessed 03 jan. 2017.

Fonseca, E. C. C. de.; Barreiros, E. C. M.; Melo, A. C. S.; Nunes, D. R. L. de.; Carneiro, M. P. (2015). Evolution of Reverse Logistics Studies Performed In the Brazilian Context: Bibliometric Analysis. Revista Produção online, Florianópolis, v. 15, n. 4, p. 1457-1480, out./dez. https://doi.org/10.14488/1676-1901.v15i4.2006.

Franco, D. (2014). Green Supply Chain Management em pequenas e medias empresas do setor químico. Master thesis. Universidade Federal de São Carlos - Centro de Ciências exatas e tecnologia - Programa de pós-graduação em engenharia de produção. São Carlos.

Geng, R., Mansouri, A., Aktas, E., \& Yen, D. Y. (2017). The role of Guanxi in green supply chain management in Asia's emerging economies: A conceptual framework. Industrial Marketing Management, v. 63, p. 1-17. https://doi.org/10.1016/j.indmarman.2017.01.002.

Govidan, K., Mathiyazhagan, K., Kannan, D., \& Haq, A. N. (2014). Barriers analysis for green supply chain management implementation in Indian industries using analytic hierarchy process. Int. J. Production Economics, 147, p. 555-568.

https://doi.org/10.1016/j.ijpe.2013.08.018.

Govidan, K., Muduli, K., Devika, K., \& Barve, A. (2016). Investigation of the influential strength of factors on adoption of green supply chain management practices: An Indian mining scenario. Resources, Conservation and Recycling, 107, p. 185-194. https://doi.org/10.1016/j.resconrec.2015.05.022.

Hair, J. F., Anderson, R. E., Tatham, R.L., \& Black, W.C. (2005). Análise multivariada de dados. 5.ed. Bookman, Porto Alegre. 
Hussain, M., Awasthi, A., \& Tiwari, M. K. (2016). Interpretive structural modeling analytic network process integrated framework for evaluating sustainable supply chain management alternatives. Applied Mathematical Modelling, 40, p. 3671-3687. https://doi.org/10.1016/j.apm.2015.09.018.

Ipea - Instituto de Pesquisa Econômica Aplicada. (2013). Estimativas do Déficit Habitacional Brasileiro (PNAD 2007 - 2012). Available at:

http://www.ipea.gov.br/portal/images/stories/PDFs/nota_tecnica/131125_notatecnicadirur0 5.pdf. Accessed 10 de feb. 2017.

Jabbour A. B. L. de S., Azevedo, F. de S., Arantes, A. F., \& Jabbour, C. J. C. (2013). Greening the supply chain: evidences of firms in Brazil. Gest. Prod. São Carlos, v.20, n.4, p. 953-962. http://dx.doi.org/10.1590/S0104-530X2013000400014.

Jabbour, A. B. L. de S., Frascareli, F. C. O., \& Jabbour, C. J. C. (2015). Green supply chain management and firms' performance: Understanding potential relationships and the role of green sourcing and some other green practices. Resources, Conservation and Recycling, 104, p. 366-374. https://doi.org/10.1016/j.resconrec.2015.07.017.

Jakhar, S. K. (2015) Performance evaluation and a flow allocation decision model for a sustainable supply chain of an apparel industry. Journal of Cleaner Production, 87, p. 391 413. https://doi.org/10.1016/j.jclepro.2014.09.089.

Jia, P., Diabat, A., \& Mathiyazhagan, K. (2015). Analyzing the SSCM practices in the mining and mineral industry by ISM approach. Resources Policy, 46, p. 76-85.

https://doi.org/10.1016/j.resourpol.2014.04.004.

Lee, S-Y., Klassen, R. D., Furlan, A., \& Vinelli, A. (2014). The green bullwhip effect: Transferring environmental requirements along a supply chain. Int. J. Production Economics, 156, p. 39-51. https://doi.org/10.1016/j.ijpe.2014.05.010.

Machado, G. B. (2013). Ciclo de vida do produto - Aberto ou Fechado. Available at: http://www.portalresiduossolidos.com/ciclo-de-vida-de-produto-aberto-ou-fechado/. Accessed 05 jan. 2017.

Marconi, M. A., \& Lakatos, E. M. (2010). Fundamentos de metodologia científica. São Paulo: Atlas.

Mathiyazhagan, K., Diabat, A., Refaie, A. A., \& Xu, L. (2015). Application of analytical hierarchy process to evaluate pressures to implement green supply chain management. Journal of Cleaner Production, 107, p. 229-236.

https://doi.org/10.1016/j.jclepro.2015.04.110.

Mathiyazhagan, K., Govindan, K., Haq, A. N., \& Geng, Y. (2013). An ISM approach for the barrier analysis in implementing green supply chain management. Journal of Cleaner Production, 47, p. 283-297. https://doi.org/10.1016/j.jclepro.2012.10.042.

Mathiyazhagan, K., \& Haq, A. N. (2013). Analysis of the influential pressures for green supply chain management adoption - an Indian perspective using interpretive structural modeling, Int J Adv Manuf Technol, 68, p. 817-833. https://doi.org/10.1007/s00170-0134946-5.

Ministry of the Environment of Brazil. (2016). Sistema Nacional do Meio Ambiente. Available at: http://www.mma.gov.br/governanca-ambiental/sistema-nacional-do-meio-ambiente.

Accessed 12 feb. 2017. 
Muduli, K., Govindan, K., Barve, A., \& Geng, Y. (2013). Barriers to green supply chain management in Indian mining industries: a graph theoretic approach. Journal of Cleaner Production, 47, p. 335-344. https://doi.org/10.1016/j.jclepro.2012.10.030.

Ojo, E., Mbowa, C., \& Akinlabi, E. T. (2014). Barriers in implementing Green Supply Chain Management in Construction industry. Proceedings of the 2014 International Conference on Industrial Engineering and Operations Management, Bali, Indonesia, January 7 - 9.

Paiva, de P. A., \& Ribeiro, M. de S. (2005). A reciclagem na construção civil: como economia de custos. Revista eletrônica de Administração, v.4, n.1.

Pucci, R. B. (2006). Logística de resíduos da construção civil atendendo à resolução Conama 307. Master thesis. Escola Politécnica da Universidade de São Paulo. São Paulo.

Rauer, J., \& Kaufmann, K. (2015). Mitigating external barriers to implementing green supply chain management: a grounded theory investigation of green-tech companies' rare earth metals supply chains. Journal of Supply Chain Management, v. 51, n. 2, p. 65-88. DOI:10.1111/jscm.12063

Raut, R. D., Narkhede, B., \& Gardas, B. B. (2017). To identify the critical success factors of sustainable supply chain management practices in the context of oil and gas industries: ISM approach. Renewable and Sustainable Energy Reviews, 68, p. 33-47. https://doi.org/10.1016/j.rser.2016.09.067.

Rehman, M. A., Seth, D., \& Shrivastava, R. L. (2016). Impact of green manufacturing practices on organizational performance in Indian context: An empirical study. Journal of Cleaner Production, 137, p. 427-448. https://doi.org/10.1016/j.jclepro.2016.07.106.

Rogers, D. S., \& Tibben-Lembke, R. S. (1998). Going Backwards: Reverse Logistics Trends and Practices. University of Nevada, Reno, Center for Logistics Management. Reverse Logistics Executive Concil.

Santos, J. da S., Bortolon, K. M., Chiroli, D. M. de G., \& Oiko, O. T. (2015). Green Logístics: conceptualization and directions for practice. Revista eletrônica em gestão, Educação e tecnologia ambiental, Santa Maria, v.19, n.2, maio-ago, p.314-331.

Sari, S. (2017). A novel multi-criteria decision framework for evaluating green supply chain management practices. Computers \& Industrial Engineering, 105, p. 338-347. https://doi.org/10.1016/j.cie.2017.01.016.

Sebrae - Serviço brasileiro de apoio às micros e pequenas empresas. Anuário do Trabalho na Micro e Pequena Empresa. (2013). Available at: http://www.sebrae.com.br/Sebrae/Portal\%20Sebrae/Anexos/Anuario\%20do\%20Trabalho $\% 20 \mathrm{Na} \% 20 \mathrm{Micro} \% 20 \mathrm{e} \% 20 \mathrm{Pequena} \% 20$ Empresa_2013.pdf. Accessed $10 \mathrm{de}$ dec. de 2017.

Shen, L., Muduli, K., \& Barve, A. (2015). Developing a sustainable development framework in the context of mining industries: AHP approach. Resources Policy, 46, p. 15-26. https://doi.org/10.1016/j.resourpol.2013.10.006.

Sheu, J-B. (2015). Power shifts and relationship quality improvement of producer-retailer green channel dyads under government intervention. Industrial Marketing Management, 50, p. 97-116. https://doi.org/10.1016/j.indmarman.2015.04.010. 
Silva, W. A., Seleme, R., \& Silva, A. C. E. (2017). Analysis of the themes related to environmental sustainability applied to logistics activities. In: VII Congresso Brasileiro de Engenharia de Produção, Ponta Grossa, Brasil. Engenharias na Indústria Alimentícia, 2017.

Silva. A. C. (2018). Mapeamento de critérios para seleção de fornecedores ambientalmente sustentáveis na cadeia logística da construção civil. Master thesis. Universidade Federal do Paraná - UFPR - Programa de pós-graduação em engenharia de produção - PPGEP, Curitiba.

Souza, de C. L. (2013). Barreiras e motivações à adoção de práticas de Green Supply Chain Management: Estudo de casos no setor de baterias automotivas. Master thesis. Universidade Estadual Paulista, Bauru.

Souza, J. L. (2014). Proposta metodológica de cálculo para a pegada hídrica na construção civil imobiliária. Doctoral thesis. Universidade Federal do Ceará, Fortaleza.

Tavares, S. F. (2006). Metodologia de análise do ciclo de vida energético de edificações residenciais brasileiras. Doctoral thesis. Universidade Federal de Santa Catarina - UFSC - Programa de pós-graduação em engenharia civil - PPGEC, Florianópolis.

Teixeira, A. A., Jabbour, C. J. C., Jabbour, A. B. L. de S., Latan, H., \& Oliveira, J. H. C. (2016). Green training and green supply chain management: evidence from Brazilian firms. Journal of Cleaner Production, 116, p. 170-176. https://doi.org/10.1016/j.jclepro.2015.12.061.

Valoto, F. M., \& Andrade, B. S. de. (2011). Construção civil e o ensino de práticas sustentáveis em prol do meio ambiente. In: XXXIX Congresso Brasileiro de Educação em Engenharia, Blumenau, Brasil.

Wang, Z., Mathiyazhagan, K., Xu, L., \& Diabat, A. (2016). A decision making trial and evaluation laboratory approach to analyze the barriers to Green Supply Chain Management adoption in a food packaging company. Journal of Cleaner Production, 117, p. 19-28. https://doi.org/10.1016/j.jclepro.2015.09.142.

Woo, C.; Kim, M. G.; Chung, Y.; Rho, J. J. (2016). Suppliers' communication capability and external green integration for green and financial performance in Korean construction industry. Journal of Cleaner Production, 112, p. 483-493. https://doi.org/10.1016/j.jclepro.2015.05.119.

Wu, C.; Barnes, D. (2016). An integrated model for green partner selection and supply chain construction. Journal of Cleaner Production, 112, p. 2114-2132.

https://doi.org/10.1016/j.jclepro.2015.02.023. 